\title{
Pengaruh Leaflet Covid-19 Terhadap Ibu Dan Bayi Pada Masa Pandemi Di Praktik Mandiri Bidan
}

\author{
The Effect Of Covid-19 Leaflet On Mother And Baby In The Pandemic \\ Period In Midwifery Practice
}

\author{
Deni Maryani ${ }^{1}$, Dara Himalaya ${ }^{2}$ \\ Prodi D3 Kebidanan Fakultas MIPA Universitas Bengkulu \\ Email: dmaryani@unib.ac.id
}

\begin{abstract}
ABSTRAK
Awal tahun 2020 Coronavirus (Covid-19) resmi ditetapkan oleh WHO sebagai penyakit infeksi berbahaya yang dapat menular ke manusia. Saat situasi pandemi kelompok yang rentan untuk tertular Covid-19 adalah bidan, dimana tugas utamanya adalah melayani kesehatan ibu dan anak ditingkat pelayanan dasar. Bidan harus memahami bagaimana protokol pelayanan kesehatan ibu dan anak, agar terhindar dari penularan Covid-19. Tujuan penelitian ini adalah menganalisis pengaruh leaflet protokol Covid-19 terhadap pelayanan ibu dan bayi, metode penelitian yang digunakan adalah quasi experiment, dengan satu grup pre dan post test. Populasi dalam penelitian adalah bidan yang membuka praktik mandiri selama pandemi Covid-19 di Kota Bengkulu, teknik pengambilan sampel dengan random sampling yaitu berjumlah 35 sampel. Analisis data dengan metode chi square. Hasil uji statistik didapatkan tingkat pengetahuan responden setelah diberikan leaflet protokol Covid-19 pelayanan ibu dan bayi, terjadi peningkatan untuk kategori baik dari $71.43 \%$ menjadi $94.29 \%$. Kategori sedang yang awalnya $57.1 \%$ menjadi $5.71 \%$, dan pengetahuan rendah dari $20.0 \%$ menjadi $0.0 \%$. Terdapat perbedaan tingkat pengetahuan bidan setelah pemberian intervensi dan sebelum pemberian intervensi dengan menggunakan media leaflet dan tidak terdapat perbedaan sikap antara sebelum intervensi dan setelah intervensi dengan menggunakan leaflet.
\end{abstract}

Kata Kunci: Leaflet, Maternal Neonatal, Covid-19

\begin{abstract}
Early 2020, the Corona virus (Covid-19) was officially designated by the WHO as a dangerous infectious disease that can be transmitted to humans. During the pandemic situation, the group that is vulnerable to contracting Covid-19 is the midwife, whose main task is maternal and child health services at the basic level. Midwives must understand how the protocol for maternal and child health services is to avoid the transmission of Covid-19. The purpose of this study was to analyze the effect of the Covid-19 leaflet protocol on maternal and infant care, the research method used was quasi-experimental, with one group pre and post test. The population in the study was midwives who opened independent practice during the Covid-19 pandemic in Bengkulu City, the sampling technique was random sampling, which returned 35 samples. Data analysis with chi square method. The results of the statistical test showed that the level of knowledge of respondents after being given the Covid-19 protocol leaflet for maternal and infant services, there was an increase in the good category from $71.43 \%$ to $94.29 \%$. The category was originally $57.1 \%$ to $5.71 \%$, and knowledge was low from $20.0 \%$ to $0.0 \%$. There is a difference in the level of knowledge after giving the intervention and before giving the intervention using leaflet media and there is no difference in attitude between before the intervention and the intervention after using the leaflet.
\end{abstract}

Keywords: Leaflet, Maternal Neonatal,Covid-19

\section{PENDAHULUAN}

Virus Covid-19 terjadi pada awal tahun 2020 dan ini menjadi masalah kesehatan dunia. Organisasi kesehatan dunia (WHO) memberikan informasi di kota Wuhan Cina terjadi kasus kluster 
Pneumonia dengan etiologi yang tidak jelas tepatnya pada tanggal 31 Desember 2019. Kasus ini terus menyebar dan bertambah parah Novel Coronavirus diketahui sebagai penyebab kluster pneumonia ini. (Kemenkes RI, 2020) Sampai dengan 14 April 2020, secara global dilaporkan 1.844.863 kasus konfimasi di 242 negara dengan 117.021 kematian. Rincian negara dan jumlah kasus sebagai berikut: China 83696 kasus konfirmasi dengan 3351 kematian, Jepang (7645 kasus, 109,Amerika Serikat (553.822 kasus, 21.972 kematian), Indonesia 4557 kasus, konfirmasi dan 399 kasus kematian. (WHO, 2020) tanda dan gejala pada infeksi Covid-19 adalah radang paruparu, kumpulan gejala gangguan pernafasan, dan bahkan mengakibatkan kematian. Serta sebagian besar kasus akan mengalami gejala demam, gangguan nafas, dan ada bercak di paru yang luas pada kedua paru Nampak pada hasil rontgen. (London, MD, 2020).

Seseorang yang paling rentan tertular penyakit ini yaitu orang yang berdekatan dalam radius satu meter dan jangka waktu 15 menit atau lebih dengan pasien positif Covid-19 termasuk seseorang yang merawat pasien terkonfirmasi Covid-19. Kelompok yang berisiko lebih tinggi terinfeksi Covid-19 adalah petugas kesehatan, mereka menjalankan tugasnya melindungi masyarakat. Tenaga kesehatan dapat mengalami kondisi seperti tekanan psikis, kelelahan, keletihan mental atau stigma.(WHO, 2020) Bidan sebagai pemberi pelayanan ditingkat dasar khususnya kesehatan ibu dan anak, dalam kondisi pandemi Covid-19 saat ini kesehatan ibu dan bayi yang menjadi tanggungjawab bidan tetap harus diberikan dimasyarakat. Tempat dilaksanakanya semua sistem pelayanan kebidanan yang diberikan oleh bidan pada tingkat mandiri adalah praktik mandiri bidan. Pelayanan kesehatan maternal sebagaimana dimaksud pada permenkes no 28 tahun 2017 bidan memberikan pelayanan pada maternal, persalinan, pasca lahir, dan KB. (Permenkes, 2017).

Bidan dalam memberikan layanan kehamilan, persalinan, bayi baru lahir, dan keluarga berencana harus memerhatikan standar operasional dan sesuai dengan prinsip-prinsip pencegahan terkonfirmasi Covid-19. Virus corona pada awal terdeteksi banyak menyerang kelompok usia lanjut, namun semakin berkembang dapat menginfeksi pada semua kelompok usia, 
mulai dari kelompok usia remaja, balita, bayi, produktif dan juga pada kelompok ibu hamil. Kasus konfirmasi di kota Bengkulu sampai awal November 2020 kasus terkonfirmasi positif berjumlah 592 orang, pasien positif meninggal berjumlah 38 jiwa, diantara pasien yang meninggal diantaranya bidan sebagai petugas kesehatan yang terlibat langsung dalam penanganan Covid-19. (Satgas COVID Kota Bengkulu) Hasil penelitian (Kabesch M, 2020) menyebutkan Rumah sakit terbesar di Bavaria tutup disebabkan karena wabah Covid-19 yang memengaruhi anggota staf termasuk tenaga medis dan paramedis. Secara global perawat dan bidan bekerja keras untuk mendeteksi kasus Covid-19 menyelamatkan nyawa atau memberikan ketenangan menghadapi kematian, mendidik masyarakat agar tenang, tenaga kesehatan mengalami konflik moral dengan meningkatnya kematian pasien. Jumlah perawat yang terinfeksi SARS-CoV-2 meningkat atau meninggal saat menjalankan tugas, petugas kesehatan membutuhkan keberanian moral, stamina yang kuat untuk bekerja digaris paling depan.

Pemakaian alat pelindung diri (APD) secara lengkap untuk melindungi bidan dari paparan virus Covid-19 terutama pada saat pertolongan persalinan sangatlah penting, karena pasien bisa saja menderita Covid-19 tanpa menimbulkan gejala dan bisa menimbulkan komplikasi pada bayi yang dilahirkan. Sejalan dengan penelitian yang dilakukan (London MD, 2020) di New York menyebutkan pasien bersalin yang terkonfirmasi Covid-19 berisiko lebih besar mengalami persalinan preterm dan membutuhkan bantuan pernafasan dengan $p$ value 0,007. World Health Organization (WHO) atau organisasi kesehatan dunia dan Kementerian kesehatan RI telah memberikan pedoman atau pegangan untuk petugas kesehatan terkait dengan pelayanan maternal (ibu hamil, bersalin pasca salin, bayi baru lahir, dan keluarga berencana), sebagai upaya perlindungan diri bagi petugas kesehatan, tetapi kenyataan dilapangan berdasarkan survey awal yang peneliti lakukan masih ada bidan belum mengetahui bagaimana penanganan pasien maternal pada masa pandemi saat ini, oleh karena itu peneliti tertarik ingin meneliti tentang pengaruh sosialisasi leafleat pengetahuan dan sikap bidan tentang protokol pelayanan maternal dan neonatal pada masa pandemi Covid-19. 
Upaya meningkatkan pengetahuan dan sikap bidan praktik mandiri maka perlu dilakukan kegiatan pemberian informasi, media yang digunakan dapat berupa media cetak (brosur dan poster), elektronik (media sosial), dan papan pengumuman (billboard). leaflet adalah salah satu media yang dapat digunakan secara efektif untuk memberikan informasi kesehatan. Lebih awet, praktis mudah dibawa kemana-mana, dapat menjangkau orang lebih banyak, ekonomis, dan mudah dipahami adalah kelebihan dari media leaflet. Menurut (Tindaon RL, 2017) pengetahuan siswa berubah sesudah dilakukan intervensi KIE dengan leaflet dari 3,3\% menjadi $43,3 \%$.

\section{METODE PENELITIAN}

Metode dalam penelitian ini menggunakan penelitian quasi experiment, dengan satu grup pre dan post test, untuk mengetahui apakah ada perbedaan ketika belum dan setelah diberikan intervensi peggunaan leaflet. Penelitian ini memiliki populasi target yaitu seluruh PMB di Kota Bengkulu yang membuka praktik mandiri selama pandemi Covid-19. Sampel penelitian dipilih dengan menggunakan teknik simple random sampling berjumlah 35 sampel. digunakan Analisa data univariat untuk menggambarkan karakteristik subjek penelitian dan analisis bivariat yaitu uji Chi square adalah dengan membandingkan frekuensi yang terjadi (observasi) dengan frekuensi harapan (expectacy).

\section{HASIL DAN PEMBAHASAN}

\section{Analisis Univariat}

Tabel 1. Distribusi Frekuensi Tingkat pengetahuan bidan tentang protokol pelayanan maternal dan neonatal saat kondisi pandemi Covid-19 sebelum diberikan leaflet

\begin{tabular}{cccc}
\hline Variabel & Kategori & $\mathrm{F}$ & $\%$ \\
\hline \multirow{2}{*}{$\begin{array}{c}\text { Pengetahuan } \\
\text { (Sebelum) }\end{array}$} & Baik & 8 & 22.86 \\
& Cukup & 20 & 57.14 \\
& Rendah & 7 & 20.00 \\
\hline \multicolumn{2}{c}{ Jumlah } & 35 & 100 \\
\hline Berdasarkan & tabel & diketahui
\end{tabular}

tingkat pengetahuan responden sebelum diberikan leaflet protokol saat kondisi Covid-19 dalam pelayanan maternal dan neonatal masuk kategori cukup, karena memiliki frekuensi terbanyak yaitu 20 orang atau sebesar $57.14 \%$. Untuk kategori baik, terdapat 8 orang atau $22.86 \%$ sedangkan 7 orang atau $20 \%$ masuk dalam kategori rendah. 
Tabel 2. Distribusi Frekuensi Tingkat pengetahuan bidan tentang protokol pelayanan maternal dan neonatal kondisi pandemi Covid19 setelah diberikan leaflet

\begin{tabular}{cccc}
\hline Variabel & Kategori & F & $\%$ \\
\hline Pengetahuan & Baik & 33 & 94.29 \\
(Setelah) & Cukup & 2 & 5.71 \\
& Rendah & 0 & 0.00 \\
\hline Jumlah & & 35 & 100 \\
\hline
\end{tabular}

Berdasarkan tabel diketahui

tingkat pengetahuan responden setelah diberikan leaflet protokol saat kondisi pandemi Covid-19 dalam pelayanan maternal dan neonatal terjadinya peningkatan untuk kategori baik, peningkatan sebesar $71.43 \%$ menjadi 94.29\%. Kategori cukup yang awalnya berjumlah 20 orang menjadi hanya 2 orang atau sebesar $5.71 \%$. sedangkan untuk kategori rendah berjumlah 0 orang. Kesimpulannya adalah bahwa terdapat peningkatan pengetahuan setelah diberikan leaflet.

Tabel 3. Distribusi Frekuensi sikap bidan tentang protokol tentang protokol pelayanan maternal dan neonatal pada masa pandemi Covid-19 sebelum diberikan leaflet

\begin{tabular}{|c|c|c|c|}
\hline Variabel & Kategori & $\mathrm{F}$ & $\%$ \\
\hline \multirow{2}{*}{$\begin{array}{c}\text { Sikap } \\
\text { (Sebelum) }\end{array}$} & Positif & 14 & 40.00 \\
\hline & Negatif & 21 & 60.00 \\
\hline \multicolumn{2}{|c|}{ Jumlah } & 35 & 100 \\
\hline
\end{tabular}

sikap responden sebelum diberikan leaflet protokol saat situasi merebaknya kasus Covid-19 dalam pelayanan maternal dan neonatal masih kebanyakan berada pada kategori sikap negatif berjumlah 21 orang atau $60 \%$. Untuk kategori sikap positif, terdapat 14 orang atau $40 \%$.

Tabel 4. Distribusi Frekuensi sikap bidan tentang protokol tentang protokol pelayanan maternal dan neonatal pada masa pandemi Covid-19 setelah diberikan leaflet

\begin{tabular}{|c|c|c|c|}
\hline Variabel & Kategori & $\mathrm{F}$ & $\%$ \\
\hline \multirow{2}{*}{$\begin{array}{c}\text { Sikap } \\
\text { (Setelah) }\end{array}$} & Positif & 22 & 62.86 \\
\hline & Negatif & 13 & 37.14 \\
\hline \multicolumn{2}{|c|}{ Jumlah } & 35 & 100 \\
\hline
\end{tabular}

bahwa terjadi peningkatan sikap responden setelah diberikan leaflet protokol pelayanan maternal dan neonatal pada masa pandemi Covid-19. Untuk kategori positif, peningkatan sebesar $22.86 \%$ sehingga menjadi $62.86 \%$ atau yang awalnya 14 orang meningkat menjadi 22 orang. Kategori sedang yang awalnya berjumlah 21 orang menjadi 13 orang atau sebesar $37.14 \%$. kesimpulan yang dapat diambil yaitu terdapat peningkatan sikap bidan terhadap protokol pelayanan maternal dan neonatal pada masa pandemi Covid19 setelah diberikan leaflet. 
2. Analisis Bivariat

Tabel 5. Pengaruh leaflet dengan pengetahuan dan sikap bidan tentang protokol pelayanan maternal dan neonatal saat situasi pandemi Covid-19
Hasil

penelitian

menunjukkan adanya perubahan pengetahuan bidan sebelum dan sesudah dilakukan intervensi KIE dengan leaflet yaitu yang berpengetahuan baik sebesar 22.9 $\%$ menjadi $94.2 \%$, pengetahuan sedang $57.1 \%$ menjadi $5.7 \%$ sedangkan pengetahuan rendah $20.0 \%$ menjadi $0.0 \%$. Sejalan dengan penelitian yang menyatakan bahwa ada peningkatan pengetahuan setelah dilakukan penyuluhan dengan media leaflet (Tindaon RL, 2017).

Sebelum diberikan leaflet tentang protokol saat situasi maraknya Covid-19 pasien maternal dan neonatal pengetahuan bidan tentang penanganan pasien di PMB mayoritas memiliki pengetahuan sedang. Setelah dilakukan KIE dan pemberian leaflet tentang protokol saat situasi maraknya Covid-19 dalam pelayanan maternal dan neonatal dari pengetahuan cukup menjadi kategori baik, terjadi peningkatan rata-rata pengetahuan sebelum metode leaflet $57.1 \%$ menjadi 94.2\% sesudah dilakukan metode leaflet dengan nilai $\mathrm{p}=0.014$, 
kesimpulan yang dapat diambil ada pengaruh metode leaflet terhadap pengetahuan bidan.

Sejalan dengan hasil

penelitian (Bont E, 2015) menyebutkan penyebaran informasi dengan menggunakan leaflet mengurangi pasien untuk berkonsultasi dokter dengan gejala penyakit yang sama, sehingga dapat meminimalisir pemakaian antibiotik pada pasien. Didukung juga dengan penelitian (Susanti N, 2017) di Kabupaten Natuna menyatakan terdapat perbedaan pengetahuan sebelum dan sesudah diberikan leaflet.

$\begin{array}{llr}\text { Salah } & \text { satu } & \text { sumber } \\ \text { informasi } & \text { dalam } & \text { rangka } \\ \text { pencegahan } & \text { penyebaran } & \text { virus }\end{array}$

Covid-19 dapat menggunakan leaflet, virus ini dapat ditularkan antar manusia melalui droplet. Seseorang yang sering berinteraksi dengan pasien Covid-19 misalnya tenaga medis, para medis dan petugas kesehatan lain adalah paling berisiko untuk terpapar infeksi virus ini. Menurut International Council of Nurses (2020) secara global, perawat dan bidan bekerja keras untuk menyelamatkan nyawa pasien dengan kasus Covid-19, memberikan kenyamanan pada pasien saat menghadapi kematian, mengedukasi diri dan masyarakat tentang langkah-langkah perlindungan dan penghentian penyebaran virus, sambil tetap merawat mereka yang terinfeksi. (Turale S, 2020).

Menjaga kebersihan diri secara individu, mencuci tangan, bila berkelompok menjaga jarak, dan melakukan kebersihan diri adalah salah satu cara pemutusan rantai interaksi virus. (Zhang Y, 2020) Ibu hamil dan janin merupakan populasi rentan terkena krisis kesehatan pada saat pandemi Covid-19, hal ini belum pernah terjadi sebelumnya. (Zaigham, 2020) data dasar dikumpukan dari bulan Februari sampai dengan April 2020 menyatakan dalam penelitianya ibu hamil trimester ketiga positif Covid-19 (68\%) mengalami demam, (34\%) batuk, Limfositopenia (59\%), reactif Protein C (70\%), (91 \%) bayi dilahirkan secara operasi caesar, satu kematian neonatal, dan satu kematian intra uterin. Virus Covid- 
19 ini dapat menyebabkan tingginya angka kesakitan dan mortalitas maternal dan neonatal, pemantauan kehamilan, persalinan yang baik dapat mencegah infeksi.

Bidan sebelum berinteraksi dan melaksanakan asuhan kebidanan memastikan peralatan dan perlengkapan sudah didesinfeksi, harus dipastikan semua steril, pasien harus membuat janji terlebih dahulu melalui telepon atau WA, dapat digunakan sebagai media menyampaikan informasi kepada pasien sebelum datang ke praktik mandiri bidan.

Media leaflet dapat diperoleh dengan mudah dan efektif sebagai media informasi, gambar yang dipilih cocok dengan capaian yang ditetapkan, dengan adanya gambar yang menarik akan menumbuhkan semangat dan keinginan dalam mengingat pesan yang berkenaan dengan gambar tersebut, leaflet dapat dengan mudah dibawa dan dibaca oleh bidan dalam keadaan santai, ketika tidak ada kegiatan. Kualitas gambar leaflet dapat mendukung untuk meningkatkan pengetahuan serta mudah dipahami oleh bidan.
2. Pengaruh leaflet protokol saat kondisi pandemi Covid-19 dalam pelayanan maternal dan neonatal terhadap sikap bidan di Praktik mandiri Bidan (PMB) Kota

\section{Bengkulu}

Hasil penelitian menunjukan adanya perubahan sikap sebelum dan setelah diberikan leaflet yaitu yang bersikap positif sebesar 14 orang $(22.86 \%)$ menjadi 22 orang $(62.86 \%)$, sedangkan yang bersikap negatif 21 orang (60\%) menjadi 13 orang (37.14\%). Dapat disimpulkan bahwa terdapat peningkatan sikap bidan terhadap penanganan pasien Covid-19 setelah diberikan leaflet. Hasil analisis Uji Chi-Square value Pearson Chi-Square untuk sikap adalah 2.468 dengan pvalue $=0.116>0.05$, maka H_0 diterima. Kesimpulanya tidak terdapat perbedaan sikap sebelum dan setelah pemberian leaflet kepada bidan dalam pencegahan infeksi dan pelaksanaan protokol pelayanan pasien maternal dan neonatal saat kondisi pandemi Covid-19. 
Hasil temuan ini sesuai dengan (Mayasari, 2019) secara statistik menyatakan pelaksanaan APN tidak ada hubunganya dengan sikap bidan dengan kinerja bidan.. pendapat orang tentang suatu pernyataan kesimpulan sindividu tentang benda yang ada, sifat orang atau suatu kegiatan, gambaran kondisi hati orang tentang suatu kejadian, ini merupakan definisi sikap (Siagian, S. 2012) Sejalan juga dengan penelitian (Longgupa, 2011) menyebutkan kinerja bidan tidak dipengaruhi oleh sikap bidan dengan nilai $(\mathrm{p}>0,05)$. Hasil penelitian menunjukan terjadi peningkatan sikap positif dalam memberikan pelayanan maternal dan neonatal, artinya bidan menerima tentang cara memberikan pelayanan dan pencegahan infeksi.

Penerimaan sikap dan perilaku didasari oleh pengetahuan, tingginya pengetahuan juga memengaruhi sikap positif petugas terhadap pelaksanaan tugasnya. Hasil uji statistik menunjukkan tidak sesuai dengan teori yang ada, dapat di terima karena kinerja tidak hanya ditentukan oleh faktor sikap saja melainkan dipengaruhi oleh banyak faktor yang saling berkaitan. Sikap adalah semua kondisi (benda, orang, hal) yang dapat diperhitungkan oleh seseorang. Pemicu seseorang atau respo-respon kejadian tertentu menentukan hubungannya dengan sikap perilaku seseorang. Suatu kondisi yang memicu munculnya suatu perbuatan atau tingkah laku. (Djunawan A, 2015).

$$
\text { Informasi yang didapat, }
$$
pengalaman, hubungan interaksi semasa hidupnya maka akan membentuk sikap manusia. Kondisi ini dapat terjadi di situasi internal rumahtangga, sekolah maupun sosial. Kontak saling ketergantungan dan menguntungkan antara seseorang dengan lingkungan sekitarnya saat itulah terjadi proses sosial. Hubungan timbal balik antar individu akan membangun suatu kebiasaan seseorang dengan lingkungan sosialnya. Kejadian yang berkesan, seseorang yang berperan penting, sosial budaya, media masa, lembaga pendidikan, tokoh agama, dan faktor emosional ini adalah faktor-faktor yang 
membentuk sikap. (Azwar, S, 2015).

Pengetahuan dan sikap dipengaruhi oleh pemberian pendidikan kesehatan hal ini adalah salah satu langkah untuk meningkatkan kesiapan bidan dalam menghadapi permasalahan pandemi. Pengetahuan akan meningkat, dan mendorong sikap positif (Peng Y, 2020) menyatakan pandemi yang melanda dunia membuat tenaga medis termasuk bidan dan perawat kewalahan, meski demikian tenaga kesehatan terus memberikan pelayanan digaris terdepan untuk membantu menangani pandemi, ini merupakan sikap positif yang dimiliki oleh tenaga kesehatan. Studi yang dilakukan (Buertey, 2020) mengeksplorasi pengetahuan, sikap, dan praktik perawat terhadap pencegahan virus corona, secara umum pengetahuan dan sikap perawat dan bidan dalam kategori baik.

Sejalan dengan penelitian (Mitchell, 2020) perawat dan bidan secara luas menyatakan bahwa mereka memahami pentingnya kebersihan terkait pencegahan infeksi corona. Sikap hanya dapat langsung ditafsirkan terlebih dahulu dari perilaku yang tertutup tidak dapat langsung manifestasi. (Sukesih, 2020)

\section{SIMPULAN DAN SARAN}

Berdasarkan analisis univariat didapatkan pengetahuan responden setelah diberikan leaflet protokol saat situasi Covid-19 dalam pelayanan maternal dan neonatal, terjadinya peningkatan untuk kategori baik, peningkatan sebesar $71.43 \%$ sehingga menjadi $94.29 \%$ atau yang awalnya hanya 8 orang meningkat menjadi 33 orang. Kategori cukup yang awalnya berjumlah 20 orang menjadi 2 orang atau sebesar $5.71 \%$. sedangkan berjumlah 0 orang untuk kategori rendah. Penggunaan Leaflet protokol pelayanan maternal dan neonatal saat situasi pandemi Covid-19 berpengaruh signifikan terhadap pengetahuan bidan praktik mandiri, tetapi leaflet tidak berpengaruh terhadap perubahan sikap dalam pencegahan infeksi, hal ini disebabkan banyak faktor untuk merubah sikap seseorang.

Peneliti memberikan saran untuk pengembangan media informasi yang lebih praktis dan mudah diakses oleh bidan sehingga memudahkan bidan 
dalam menerima informasi terkait pelayanan maternal dan neonatal di praktik mandiri bidan terutama pada saat pandemi Covid saat ini.

\section{DAFTAR PUSTAKA}

Azwar S, 2015. Penyusunan Skala Psikologi, Yogyakarta : Pustaka Pelajar.

Bont E, Alink M, Falkenberg F, Dinant GJ, Cals J. Patient information leaflets to reduce antibiotic use and reconsultation ratesin general practice: a systematic review. BMJ. 2015;5.1-8.

Buertey A. et al. Knowledge, Attitudes and Practices of Nurses in the Tamale Metropolis Towards Coronavirus Prevention. DJMR. 2020.2(6).34-47.

Djunawan A. Analisis hubungan kerjasama, motivasi, dan sikap bidan dengan kinerja dalam pelayanan antenatal pada era JKN dikecamatan Kejayan Kabupaten Pasuruan. Jurnal Administrasi Kesehatan. 2015.3(1).11-2020

Kabesch M, et al. Successful containment of Covid-19 outbreak in a large maternity and perinatal center while continuing clinical service. WILEY. 2020;31.560-4.

Kemenkes RI. Pedoman pencegahan dan pengendalian coronavirus disease (COVID 19). Direktorat jenderal pencegahan dan pengendalian penyakit. Jakarta: Kementrian Kesehatan Republik Indonesia, 2020.Revisi ke 3.

London MD, et al. The Relationship between Status at Presentation and Outcomes among Pregnant
Women with COVID-19. AmJPerinatol.2020;37.991-994. Longgupa, L.W. (2011). Pengaruh Faktor Pengetahuan, Sikap dan Pelatihan Asuhan Persalinan Normal Pada Kinerja Bidan Dalam Pertolongan Persalinan Normal Suatu Studi Eksploratif di Kota Palu Provinsi Sulawesi Tengah. JIK. I( 16).781-785.

Mayasari D, Hardisman, Desmiwarti. Analisis Faktor Determinan Kinerja Bidan dalam Pelaksanaan Asuhan Persalinan Normal di Kabupaten Merangin Tahun 2019. JIUBJ.2019.19(3).554-559.

Mitchell BG, Russo PL, Kiernan M, Curryer C. Nurses' and midwives' cleaning knowledge, attitudesand practices: An Australian study. 2020. Terdesia dari:https://www.ncbi.nlm.nih.gov /pmc/articles/PMC7526607/pdf/m ain.pdf

Peng Y, et.al. A Cross-Sectional Survey of Knowledge, Attitude and Practice Associated with COVID-19 among Undergraduate Students in China. Research square.BMC.2020.20(1292).1-

13. Tersedia dari:https://assets.researchsquare .com/files/rs21185/v3/81b1450a-ed58-41ddbc6a-face87923453.

Peraturan Menteri Kesehatan (PERMENKES) No28 tahun 2017. Tentang izin dan penyelenggaraan praktik bidan.: [diunduh tangal 18 April 2020] Tersedia dari,http://www.ibi.or.id/media/P MK\%20No.\%2028\%20ttg\%201zin\%2 0dan\%20Penyelenggaraan\%20Prak tik\%20Bidan.pdf. 
Siagian, S. 2012.Teori motivasi dan aplikasinya . Jakarta : Rineka cipta.

Sukesih. Gambaran Komunikasi SBAR Terhadap Sikap Dan Perilaku Perawat The 10th University Research Colloqium 2019. STIKES Muhammadiyah Gombong.

Susanti N, Qodariah, Harnani Y, Rasyid Z. Efektifitas leaflet terhadap pengetahuan dan mengatur pola makan lansia penderita hipertensi di puskesmas serasan kabupaten Natuna. Jurnal Photon. 2017;7(2).33-8.

Tindaon RL. Pengaruh komunikasi, informasi, dan edukasi (KIE) melalui media leaflet dan video terhadap pengetahuan dan sikap remaja tentang paparan pornografi di SMP negeri 1 Sidamanik Kec Sidamanik Kab Simalungun tahun 2016. JUMANTIK. 2017;3(1).44-64.

Turale S, Meechamnan C, Kunaviktikul W. Challenging times: ethics, nursing and the COVID-19 pandemic. PMC. 2020;67(2).164-7.

WHO. 2020. Corornavirus Disese situation report-85. .[diunduh 17 April 2020] tersedia dari https://www.who.int/docs/default -source/coronaviruse/situationreports/20200414-sitrep-85-covid19.pdf?sfvrsn=7b8629bb 2.

Zhaigham M, Andersson O. Maternal and perinatal outcomes with COVID-19: A systematic review of 108 pregnancies. AOGS. 2020.(99).823-829.

Zhang Y, Zhao Q, Hu B. Communitybased prevention and control of COVID-19: Experience from China. Am J Infect Control. 2020;0(2020):34.
WHO. 2020. Corornavirus Disese situation report-85. .[diunduh 17 April 2020] tersedia dari https://www.who.int/docs/defaul t-source/coronaviruse/situationreports/20200414-sitrep-85covid19.pdf?sfvrsn $=7 \mathrm{~b} 8629 \mathrm{bb} 2$. 